Józef Łukasz

Międzyuczelniany Instytut Muzyki Kościelnej, Kraków

\title{
Sprawozdanie z VIII Dni Muzyki Kościelnej
}

Dni Muzyki Kościelnej odbywające się co roku w Krakowie stają się powoli tradycją w środowisku muzycznym tego miasta. $\mathrm{Z}$ biegiem czasu nabierają coraz bardziej pokaźnych rozmiarów, a także, co najważniejsze, obfitują w coraz ciekawsze koncerty i interesujące wydarzenia. VIII Dni Muzyki Kościelnej, które odbyły się w listopadzie roku ubiegłego, z pewnością pozostaną w pamięci tych, którzy je organizowali, tych, którzy brali w nich czynny udział, oraz tych, którzy z wytęsknieniem ich wyczekiwali.

Wszystko zaczęło się w roku 2005...

I Dni Muzyki Kościelnej rozpoczęły się w sobotę 19 listopada 2005 roku od uroczystej mszy świętej pod przewodnictwem biskupa Jana Zająca. Zawierały się w nich różnego rodzaju koncerty (chóralne, jak również organowe), nabożeństwa oraz sympozjum naukowe z okazji 50. rocznicy wydania przez Piusa XII encykliki Musicae sacrae disciplina. Niewątpliwie ważnym wydarzeniem tamtych dni było poświęcenie przez arcybiskupa Stanisława Dziwisza organów w kościele pw. Miłosierdzia Bożego w Skawinie. Taki był początek.

Przez 8 lat wiele rzeczy uległo zmianie. Dni Muzyki Kościelnej zyskały znaczącą rangę. Nietrudno zauważyć, iż starania organizatorów przynoszą efekty, a takim z pewnością były VIII Dni Muzyki Kościelnej, które odbywały się od 15 do 27 listopada roku 2012. Ich program przedstawiał się następująco:

15 listopada 2012 (czwartek)

Archidiecezjalna Szkoła Muzyczna, Kraków, ul. Prosta 35 A

- Recital organowy - Radosław Marzec

16 listopada 2012 (piątek)

Archidiecezjalna Szkoła Muzyczna, Kraków, ul. Prosta 35 A

- Kurs Interpretacji Organowej - dr hab. Radosław Marzec, prof. AM w Bydgoszczy

19.30, kościół uniwersytecki UPJPII pw. św. Marka - Kraków, ul św. Marka 10

- Koncert chóralny: zespół wokalny Alter ut, Węgry; Szilveszter Rostetter (dyrygent)

W programie: polska i węgierska muzyka chóralna

Słowo wprowadzające: dr hab. Wiesław Delimat, prof. UPJPII

20 listopada 2012 (wtorek)

kościół oo. Kapucynów - Kraków, ul. Loretańska 11 
- Koncert: Mauro Piazzi, Włochy (puzon), s. Susi Ferfoglia (organy)

W programie: muzyka kameralna i organowa

Słowo wprowadzające: ks. dr Stanisław Mieszczak SCJ

\section{1 listopada 2012 (środa)}

Bazylika św. Floriana - Kraków, ul. Warszawska 1b

- Koncert: schola „Flores Rosarum”, s. Susi Ferfoglia (dyrygent), Henryk Jan Botor (organy)

W programie: muzyka św. Hildegardy z Bingen oraz improwizacje organowe

Słowo wprowadzające: ks. dr Wojciech Kałamarz CM

22 listopada 2012 (czwartek) Wspomnienie św. Cecylii, patronki muzyki kościelnej

kościół pw. św. Stanisława BM - Kraków, ul. Półkole 9a

- Koncert oratoryjny - Chór Psalmodia UPJPII, Włodzimierz Siedlik (dyrygent), Marek Pawełek (organy)

W programie: muzyka Stanisława Moniuszki

Słowo wprowadzające: mgr Krzysztof Michałek

\section{3 listopada 2012 (piątek)}

Archidiecezjalna Szkoła Muzyczna, Kraków, ul. Prosta 35 A

- V Krakowski Konkurs Młodych Organistów - etap I

\section{4 listopada 2012 (sobota)}

POSM II st. im. Fryderyka Chopina, Kraków, ul. Basztowa 6

- V Krakowski Konkurs Młodych Organistów - etap II

oraz Bazylika Ofiarowania NMP, Wadowice, plac Jana Pawła II 1

- dzień skupienia organistów Archidiecezji Krakowskiej, prowadzący: ks. mgr lic. Paweł Kummer

25 listopada 2012 (niedziela) Uroczystość Chrystusa Króla Wszechświata

Akademia Muzyczna, Kraków, ul. św. Tomasza 43

- V Krakowski Konkurs Młodych Organistów - koncert laureatów

Koncerty w kościołach Archidiecezji Krakowskiej

12.45 - kościół parafialny NMP w Strumianach

15.30 - kościół parafialny św.św. Piotra i Pawła w Bolechowicach

19.45 - kościół parafialny Najświętszego Salwatora, Kraków-Salwator

19.45 - kościół XX Misjonarzy, Kraków-Stradom

20.00 - kościół parafialny NMP Królowej Polski, Kraków-Bieńczyce

18.00 - kościół pw. św.św. Piotra i Pawła, Kraków, ul. Grodzka 52

- Uroczysta msza święta w języku łacińskim, celebrans: abp Stanisław Budzik, metropolita lubelski

- Chór Archidiecezjalnej Szkoły Muzycznej, Chór Canticum Canticorum, Orkiestra L' Estate Armonico, Wiesław Delimat (dyrygent), Krzysztof Michałek (organy)

W programie: Joseph Haydn - Missa S. Joannis de Deo

\section{6 listopada 2012 (poniedziałek)}

Akademia Muzyczna w Krakowie, Sala kameralna im. prof. Marka Stachowskiego

9.30 - sesja naukowa pt. „Muzyka w przestrzeni sakralnej”

Powitanie gości: prof. dr hab. Wojciech Widłak, Dziekan Wydziału Twórczości, Interpretacji i Edukacji Muzycznej Akademii Muzycznej w Krakowie

Prowadzenie: ks. prof. dr Kazimierz Szymonik (Uniwersytet Kardynała Stefana Wyszyńskiego, Uniwersytet Muzyczny Fryderyka Chopina, Warszawa)

- wykład I - ks. dr hab. Jacek Bramorski, prof. AM (Akademia Muzyczna, Gdańsk), Teologiczno-estetyczne wyznaczniki sakralności dzieta muzycznego

- wykład II - mgr Andrzej Mikulski (Centrum Jana Pawła II, Kraków), Architektoniczne uwarunkowania dla prezentacji muzyki we wnętrzu kościota

- wykład III - ks. dr Stanisław Mieszczak SCJ (Uniwersytet Papieski Jana Pawła II w Krakowie, Kraków), Teologia miejsca świętego

- wykład IV - ks. prof. dr hab. Ireneusz Pawlak (Katolicki Uniwersytet Lubelski Jana Pawła II, Lublin), Występy muzyczne w kościotach 
- Debata z udziałem prelegentów na temat: Świątynia miejscem świętym dla muzyki?, prowadzenie: ks. prof. dr hab. Andrzej Zając (Uniwersytet Papieski Jana Pawła II w Krakowie, Kraków)

- Zakończenie sesji: ks. prof. dr hab. Jan Szczepaniak, Dziekan Wydziału Historii i Dziedzictwa Kulturowego Uniwersytetu Papieskiego Jana Pawła II

27 listopada 2012 (wtorek)

Międzyuczelniany Instytut Muzyki Kościelnej, Kraków, ul. Prosta 35 A, sala 41

- Kurs interpretacji sakralnej muzyki chóralnej, chór Międzyuczelnianego Instytutu Muzyki Kościelnej, Jan Łukaszewski - prowadzenie

godz. 19.00 - kościół Świętego Krzyża, Kraków, ul. św. Krzyża 23

- Uroczyste nieszpory, Schola Gregoriańska MIMK, Krzysztof Pawlisz (organy), celebrans: ks. dr hab. Robert Tyrała

Opis wybranych wydarzeń z VIII Dni Muzyki Kościelnej widziany oczami studenta Międzyuczelnianego Instytutu Muzyki Kościelnej w Krakowie

\section{5 listopada}

Święto Chrystusa Króla Wszechświata, w Kościele katolickim odbywające się w ostatnią niedzielę okresu zwykłego, przypadło na dzień 25 listopada. To właśnie w tym dniu w kościele pw. świętych Piotra i Pawła przy ulicy Grodzkiej 52a odbyła się tradycyjna dla Dni Muzyki Kościelnej uroczysta msza święta, którą w tym roku celebrował metropolita lubelski arcybiskup Stanisław Budzik. Było to niesamowite przeżycie, ale po kolei.

Przed samym wejściem do kościoła odczuwało się już atmosferę sacrum. Ludzie wchodzili w skupieniu do świątyni, nadchodzili z różnych stron i stopniowo zapełniali kościół. Obraz mąciła jednak pewna uliczna śpiewaczka, która przed wejściem do przybytku Pańskiego wykonywała nieudolnie Bogurodzicę, na szczęście mało kto zwracał na nią uwagę, myśląc o uroczystej Eucharystii. Wchodząc w mury świątyni można było zauważyć, jak wiele osób ściągnęło na tę mszę świętą. Wszystkie miejsca zostały zajęte, a wielu ludzi musiało się zadowolić miejscami stojącymi. Nic jednak nie zmąciło ciszy przed Eucharystią.

$\mathrm{O}$ wyznaczonej porze odezwał się dzwonek na rozpoczęcie liturgii. Z organów popłynęły dźwięki improwizacji organowej towarzyszące procesji na wejście, następnie zabrzmiała uroczyście pieśn Króluj nam, Chryste. Trzeba przyznać, że dzień przed obroną pracy doktorskiej pan magister Krzysztof Michałek fantastycznie akompaniował i improwizował. Piękna harmonia „pociągnęła” ludzi, którzy razem z organistą śpiewali pieśń. Arcybiskup Budzik odprawiał mszę świętą w języku łacińskim, a chór ASM wraz z chórem Canticum Canticorum przy akompaniamencie orkiestry L'Estate Armonico pod dyrekcją dra hab. Wiesława Delimata, profesora UPJPII, wykonywały części stałe z Missa s. Joannis de Deo J. Haydna. Święto Chrystusa Króla było obchodzone bardzo godnie. Czytania z odśpiewaną formułą „Verbum Domini” i odpowiedzią całego ludu Bożego „Deo gratias" dały dowód na to, iż nie trzeba obawiać się języka łacińskiego w liturgii. 
Moim zdaniem, nadało to całej celebracji innego wymiaru, niespotykanego na co dzień nawet w takim mieście jak Kraków.

Po homilii wierni odmówili Credo w języku polskim. Co ciekawe, w planie uroczystości było zaznaczone, że Credo będzie śpiewane przez chór, jednak troska o przejrzystość liturgii oraz dbałość o zgodność z postanowieniami soborowymi wzięły górę nad pięknem tej części. Według mnie jest to doskonały przykład na to, że muzycy w kościele służą Bogu i nie przedkładają chęci pokazania swoich umiejętności artystycznych ponad to co najważniejsze, czyli mszę świętą. Na przygotowanie darów odśpiewaliśmy pieśn Chryste, króluj, Chryste, zwyciężaj. Dzięki folderom wierni odpowiadali na wezwania celebransa, przez co całość brzmiała bardzo podniośle. Nikt nie patrzył na zegarek, nikt się nie oglądał, wszyscy byli zatopieni w modlitwie.

Podczas Komunii świętej z organów popłynął utwór Oliviera Messiaena Le banquet céleste. Wywołało to we mnie mieszane uczucia. Z jednej strony, kompozycja ma bardzo spokojny i kontemplacyjny charakter, z drugiej jednak strony, inna harmonia niż ta, do której przyzwyczajony jest przeciętny słuchacz, spowodowała lekkie zdziwienie na twarzach zgromadzonych. Dużo jeszcze pracy przed muzykami miasta Krakowa, aby zbudować w ludziach wrażliwość na piękno muzyki i niejako wyzwolić ich z wszechobecnego kiczu, wylewającego się z każdego głośnika w codziennym, szarym świecie.

Po błogosławieństwie kolejny popis dał pan Krzysztof Michałek, grając pieśń Chrystus Wodzem, Chrystus Królem, a następnie improwizując na jej temat. Wielu ludzi pozostało jeszcze w kościele, aby posłuchać tych pięknych dźwięków wydobywających się z organów. Na co dzień nie zdarza się to zbyt często.

Trzeba przyznać, że muzyka podczas Eucharystii stała na bardzo wysokim poziomie. Nie było to byle jakie odegranie swoich partii, jak na co dzień słyszymy $\mathrm{w}$ wielu polskich kościołach, ale doskonale zorganizowane muzycznie wydarzenie, które podkreśliło to ważne święto, a także rolę, jaką muzycy pełnią w Kościele.

\section{6 listopada}

To właśnie tego dnia odbyło się wydarzenie mające największe znaczenie dla tych, którzy na co dzień zajmują się muzyką w liturgii oraz koncertowaniem w kościołach. Sesja naukowa pt. „Muzyka w przestrzeni sakralnej” dostarczyła kilku odpowiedzi na frapujące słuchaczy pytania, jednak przede wszystkim... obudziła kolejne! Prelegenci stanęli na wysokości zadania. Wykłady były bardzo ciekawe, a żywo reagujące audytorium nie omieszkało podejmować nurtujących kwestii.

Po powitaniu gości przez prof. dra hab. Wojciecha Widłaka - dziekana Wydziału Twórczości, Interpretacji i Edukacji Muzycznej - swój wykład rozpoczął ks. dr hab. Jacek Bramorski. Jego prelekcja miała tytuł: Teologiczno-estetyczne wyznaczniki sakralności dzieła muzycznego, i pobudziła słuchaczy do myślenia. 
Tezy podparte przykładami, jak i dobra argumentacja prowadzącego przyczyniły się znacznie do zrozumienia przez słuchaczy podejmowanego zagadnienia.

Kolejnym prelegentem był architekt, mgr Andrzej Mikulski. Temat jego wykładu brzmiał: Architektoniczne uwarunkowania dla prezentacji muzyki we wnetrzu kościota, jednak w rzeczywistości skupił się on na budowie Centrum Jana Pawła II, materiałach budowlanych, symbolice itp. Temat również bardzo ciekawy, jednak nie taki, który by interesował większość audytorium. Znalazło się kilka osób, które podjęły dyskusję o budownictwie, jednak nie poszła ona w stronę zadanego tematu, a skupiła się na budowie kościołów ogólnie. Trochę szkoda, że nie było możliwości posłuchania rozmowy na temat akustyki.

Wykład III prowadzony przez ks. dra Stanisława Mieszczaka SCJ poświęcony był Teologii miejsca świętego. Po interesującej prezentacji tematu prelegent odpowiadał celnie na pytania publiczności.

Najciekawszym wykładem w sesji był w moim odczuciu ten, który prowadził ks. prof. dr hab. Ireneusz Pawlak. Dotyczył on występów muzycznych w kościołach, czyli kwestii bardzo drażliwej i spornej. Prelegent bardzo jasno przedstawił stanowisko Kościoła, podparł je dokumentami i postanowieniami soborowymi. Wskazał zagrożenia, jakie niesie ze sobą wprowadzanie „obcej” oraz kiczowatej muzyki w mury naszych świątyń. I chociaż wiele kwestii wciąż wymaga dyskusji i uregulowania, to wstęp został uczyniony.

Cała konferencja została zwieńczona dyskusją, którą prowadził ks. prof. dr hab. Andrzej Zając. Większość pytań dotyczyła (co oczywiste) wykonawstwa muzyki w świątyniach, nie zabrakło także innych kwestii związanych z podejmowanymi zagadnieniami. Gdyby nie ograniczony czas, dyskusja trwałaby z pewnością do późnych godzin nocnych, pozostawiając wciąż wiele nierozwiązanych problemów.

\section{7 listopada}

Dzień zakończenia VIII Dni Muzyki Kościelnej był doskonałym podsumowaniem całego wydarzenia. Studenci Międzyuczelnianego Instytutu Muzyki Kościelnej mieli możliwość wzięcia udziału w Mistrzowskim Kursie Interpretacji Sakralnej Muzyki Chóralnej, prowadzonym przez uznanego chórmistrza Jana Łukaszewskiego. W celu lepszego przybliżenia prezentowanego zagadnienia dyrygent omówił kontekst historyczny epok, w których powstawały śpiewane przez chór MIMK utwory. Kurs poprzedził wykład, który został wzbogacony prezentacją dzieł sztuki wielkich mistrzów. Jan Łukaszewski w bardzo ciekawy sposób połączył obrazy z muzyką. Zagadnienie programowości w muzyce nie jest nikomu obce, jednak spojrzenie na nie z tego punktu widzenia otworzyło przed słuchaczami wiele nowych perspektyw interpretacyjnych.

Po wstępie teoretycznym przyszedł czas na zajęcia praktyczne. Sytuacja, w której żaden ze studentów (studentek) nie chciał wychodzić przed zespół, nie była niczym nowym, jednak wraz z upływem czasu uczestnicy nabierali coraz większej 
śmiałości i bardziej żywiołowo wdawali się w dyskusje z prowadzącym. Swoją pasją i zaangażowaniem Jan Łukaszewski udowodnił, że z pewnością jest wybitnym specjalistą w swojej dziedzinie, a prowadzone przez niego zajęcia, chociaż bardzo krótkie, na długo zapadły w pamięci uczestników.

Wieczorem o godzinie 19.00 w kościele pw. Świętego Krzyża w Krakowie odbyło się ostatnie wydarzenie, zamykające VIII Dni Muzyki Kościelnej. Były to uroczyste Nieszpory ku czci Chrystusa Króla. Celebrował je dyrektor MIMK ks. dr hab. Robert Tyrała. Wspaniałymi improwizacjami organowymi w stylu włoskim wzbogacił je dr Krzysztof Pawlisz, akompaniując równocześnie scholi gregoriańskiej, złożonej ze studentów i pedagogów Instytutu. Trudno mi obiektywnie ocenić całe wydarzenie z uwagi na to, iż byłem jednym z jego czynnych uczestników. Po rozmowach z osobami, które nie były w nią zaangażowane, mogę stwierdzić, że było to godne uwieńczenie całego przedsięwzięcia.

\section{Podsumowanie}

VIII Dni Muzyki Kościelnej trwały 12 dni. Rozpoczęły się bardzo kameralnie od koncertu prof. Marca z AM w Bydgoszczy w Archidiecezjalnej Szkole Muzycznej im. Franciszka Macharskiego w Krakowie. Obfitowały w wiele ciekawych i barwnych wydarzeń. Szczytowym ich dniem była według mnie niedziela Chrystusa Króla Wszechświata, kiedy to odbyły się uroczysta msza święta oraz koncerty w krakowskich kościołach, a także koncert laureatów V Krakowskiego Konkursu Młodych Organistów. Z pewnością cieszyć może udział wielu słuchaczy podczas koncertów, uroczystej mszy świętej oraz Nieszporów. Niestety, w porównaniu z innymi „kulturalnymi” wydarzeniami odbywającymi się w Królewskim Mieście Krakowie jest to wciąż niewielka grupa. Bez wątpienia ciężko się przebić z taką inicjatywą do szerokich mas społeczeństwa. Wynika to z faktu, iż prezentowana muzyka wymaga skupienia, kontemplacji i chwilowego zatrzymania się. W dzisiejszym świecie jest to dla wielu ludzi nie lada problem, stąd też mając do wyboru sztukę na bardzo wysokim poziomie podaną de facto "na tacy” oraz pseudorozrywkę niskich lotów, człowiek wybiera bardzo miałkie programy w telewizji czy quasi-muzykę opartą na kilku akordach i powtarzanym tekście. Inicjatywy organizowane przez ludzi kultury, takie jak Dni Muzyki Kościelnej, mogą moim zdaniem przyczynić się do odwrócenia tej niepokojącej tendencji obecnej przecież w całym społeczeństwie. Kolejną okazją ku temu będą z pewnością IX Dni Muzyki Kościelnej, które odbędą się jesienią 2013 roku. Czekamy na nie z niecierpliwością! 